\title{
Report on the First International Conference on Food Chemistry \& Technology (FCT-2015)
}

\author{
Mun Yhung Jung \\ College of Food Science, Woosuk University, Republic of Korea
}

"Correspondence to:

Mun Yhung Jung, $\mathrm{PhD}$

College of Food Science

Woosuk University, Samnye-eup

Wanju-gun, Jeonbuk Province 565-701

Republic of Korea

Tel: 82-63-290-1438

Fax: 82-63-291-9312

E-mail: munjung@woosuk.ac.kr

Received: April 19, 2016

Accepted: April 25, 2016

Published: April 26, 2016

Citation: Jung MY. 2016. Report on the First International Conference on Food Chemistry \& Technology (FCT-2015). J Food Chem Nanotechnol 2(2): $77-78$.

Copyright: (C) 2016 Jung. This is an Open Access article distributed under the terms of the Creative Commons Attribution 4.0 International License (CC-BY) (http://creativecommons.org/licenses/ by/4.0/) which permits commercial use, including reproduction, adaptation, and distribution of the article provided the original author and source are credited.

Published by United Scientific Group

\section{Meeting Report}

Food Chemistry \& Technology (FCT-2015) has concluded successfully on November 18,2015. The three-day conference was organized by United Scientific Group (USG) during November 16-18, 2015 at DoubleTree by Hilton, San Francisco, USA. The conference was themed around "Exploring the recent trends, innovation E' emerging technologies for food research and development".

FCT-2015 has featured many highly informative and interactive sessions to encourage the exchange of ideas across a broad range of disciplines in food sciences. The meeting witnessed exclusive discussions on latest trends in food research and its applications in food chemistry and technology.

The conference has gathered professors, researchers, scientists, academicians, industries and other professionals in food research to exchange and discuss their original research results, practical development experiences and technological achievements.

\section{FCT-2015 rendered presentations on:}

Antioxidants and lipid oxidation in foods; Bioactive constituents, micronutrients food additives and ingredients; Analytical methods for food components; Food contamination and toxic components; Foodborne infections and diseases; Food safety and control; Food public health and food policy; Food supplements and food labels; Food quality and management; Nutrition and nutritional management; Changes in food components during fermentation; Food biochemistry and food microbiology; Food technology; Food processing and packaging technologies; Food and bioprocess technology; Agriculture biotechnology; Food nanotechnology; and Industrial applications of food technology.

\section{FCT-2015 highlights:}

In the beautiful city of San Francisco, the opening day of the conference (November 16,2015) started with the Prof.Mun YhungJung, Woosuk University, South Korea, keynote speech on "Simple and Fast Gas Chromatography-Tandem Mass Spectrometry for the Analysis of Policosanols in Various Vegetable Oils and Green Tea Leaves". Prof. Romdhane Karoui, Artois University, France, delivered the second keynote of day 1 on "Use of Rapid Analytical Methods for Determination of the Quality of Food Products". Followed by Dr. Naofumi Morita, Toyo College of Food Technology, Japan, keynote presentations on "Germination and Graded Polishing of Cereal and Pseudo-Cereal Improves Nutritional and Functional Properties". On behalf of Prof. Margaret Barth, her colleague Dr. Shasha Zheng, California Baptist University, USA presented keynote talk on "Phytonutrients and Antioxidant Activity in Traditional, Native American Edible Plants from Southern California".

After the keynotes, the session continued with the speaker presentations on 
Antioxidants and lipid oxidation in foods, Analytical methods for food components, Enzymatic reactions in foods, Food contamination and toxic components, Bioactive constituents, Micronutrients, Food additives and ingredients and the day ended with poster presentations session- 1 and a great socializing reception in the evening.

Second day of the conference commenced with the speaker session on Functional foods and functionality, Food public health and food policy, Food supplements and food labels, Food quality and management, Foodborne infections and diseases, Nutrition and nutritional management, Food safety and control, Food biochemistry and food microbiology and ended with poster presentations session-2.
The last day of the conference was mainly focused on Food technology, Food nanotechnology, Food processing and packaging technologies, Industrial applications of food technology, Food and bioprocess technology, Tools and techniques in food technology, Agriculture biotechnology. FCT-2015 finally concluded with the closing ceremony and certificate distribution.

USG is obliged to the committee members, speakers and delegates of FCT-2015 for their outstanding support and participation. The proceeding of the conference will be published in the Journal of Food Chemistry and Nanotechnology launched during FCT-2015 by founding Editor-in-Chief Prof. Mun Yhung Jung, Woosuk University, South Korea. 